OPEN ACCESS

Edited by:

Tilmann Harder,

University of Bremen, Germany

Reviewed by:

Hans Uwe Dahms,

Kaohsiung Medical University, Taiwan

David Kimmel,

National Marine Fisheries Service

(NOAA), United States

${ }^{*}$ Correspondence:

Eun Jin Yang

ejyang@kopri.re.kr

Specialty section:

This article was submitted to Marine Ecosystem Ecology,

a section of the journal

Frontiers in Marine Science

Received: 27 April 2020

Accepted: 03 July 2020

Published: 22 July 2020

Citation:

Kim J-H, Cho K-H, La HS,

Choy EJ, Matsuno K, Kang S-H, Kim W and Yang EJ (2020) Mass

Occurrence of Pacific Copepods

in the Southern Chukchi Sea During

Summer: Implications of the

High-Temperature Bering Summer

Water. Front. Mar. Sci. 7:612.

doi: 10.3389/fmars.2020.00612

\section{Mass Occurrence of Pacific Copepods in the Southern Chukchi Sea During Summer: Implications of the High-Temperature Bering Summer Water}

\author{
Jee-Hoon Kim ${ }^{1}$, Kyoung-Ho Cho', Hyoung Sul La', Eun Jung Choy', Kohei Matsuno,3, \\ Sung-Ho Kang ${ }^{1}$, Won Kim ${ }^{4}$ and Eun Jin Yang ${ }^{1 *}$ \\ ${ }^{1}$ Korea Polar Research Institute, Incheon, South Korea, ${ }^{2}$ Graduate School of Fisheries Science, Hokkaido University, \\ Sapporo, Japan, ${ }^{3}$ Arctic Research Centre, Hokkaido University, Sapporo, Japan, ${ }^{4}$ School of Biological Sciences, Seoul \\ National University, Seoul, South Korea
}

The Bering Strait is the only gateway to the Chukchi Sea from the Pacific Ocean and is a major route of Pacific water inflow. We recently investigated the occurrence of Pacific copepod species along with the warming of the Chukchi Sea and sought to identify the cause of the mass occurrence these copepods through an analysis of the water masses flowing through the Bering Strait. Zooplankton and Conductivity-Temperature-Depth (CTD) data collection was conducted in the Chukchi Sea and Bering Strait from 2014 to 2016. In addition, mooring systems installed in the Bering Strait were analyzed to obtain water temperature and salinity data during summer to understand the properties of the water masses. In 2015, a high abundance of Pacific copepod species (Eucalanus bungii, Metridia pacifica, and Neocalanus spp.) was observed in Bering Summer Water (BSW), which was relatively warm compared to measurements obtained from 2014 to 2016. As further confirmation, our results were consistent with 2007, 2009, and 2012 data, which showed that the abundance of Pacific copepod species was proportional to the temperature of the BSW entering the Chukchi Sea. In conclusion, we reconfirmed that Pacific copepod species are entering the Chukchi Sea along with BSW, and we newly discovered that their high abundance coincided with the relatively warm BSW, instead of other water masses. These findings suggest that the inflow of the high-temperature $\mathrm{BSW}\left(>3^{\circ} \mathrm{C}\right.$ ) plays an important role in the mass occurrence of Pacific copepod species in the southern Chukchi Sea.

Keywords: Pacific copepod, Arctic, Chukchi Sea, Bering Summer Water, mass occurrence

\section{INTRODUCTION}

Large amounts of Pacific heat, nutrients, freshwater, and biota pass through the shallow Bering Strait and into the Chukchi Sea, entering the Arctic (Pickart et al., 2010; Corlett and Pickart, 2017; Danielson et al., 2017). Since the 2000s, relatively warm Pacific waters passing through the Bering Strait into the Chukchi Sea during summer have played a significant role on changes in the marine 
environment (e.g., rising water temperatures and melting ice) of the Chukchi Sea (Shimada et al., 2006; Brugler et al., 2014; Wood et al., 2015; Pickart et al., 2016). Zooplankton communities are more vulnerable to environmental change in polar oceans because they are affected by various rapid hydrographical changes, such as the formation/melting of sea ice, surface cooling, and convection (Matsuno et al., 2011, 2016; Spear et al., 2019). The increasing water temperature and Pacific water inflow are also causing changes in the zooplankton community across the Arctic boundary (Nelson et al., 2009). Among these changes is the appearance, reported in previous studies, of a large number of Pacific copepod species (Eucalanus bungii, Metridia pacifica, and Neocalanus spp.) in the Chukchi Sea since the late 2000s (Matsuno et al., 2011; Ershova et al., 2015a,b).

The occurrence and community structure of Pacific copepod species in the Chukchi Sea are influenced by the composition of water masses flowing from the Bering Sea (Hopcroft et al., 2010; Eisner et al., 2013; Questel et al., 2013; Ershova et al., 2015b; Pinchuk and Eisner, 2017; Xu et al., 2018; Spear et al., 2019). In the southern Chukchi Sea, the northward shift of Pacific zooplankton species is largely correlated with the inflow of Bering Summer Water (BSW) through the Bering Strait (Matsuno et al., 2011; Ershova et al., 2015b). Additionally, an increase in Pacific copepod species in the Chukchi Sea is associated with a "warm state" of sea surface temperature (Pinchuk and Eisner, 2017; Spear et al., 2019). However, it is difficult to predict the changes in species abundance and community structure because of the effects of seasonal and interannual variations on the influx of Pacific waters (Brugler et al., 2014; Corlett and Pickart, 2017). In particular, the drivers of the interannual variation in the occurrence and community structure of Pacific copepod species in the Chukchi Sea are not fully understood. Therefore, to verify the response of marine organisms and their communities to changes in the marine environment, it is necessary to observe oceanographic environmental factors over the long term.

In one sense, it is thought that the reasons for the mass occurrence of the Pacific copepod species in the Chukchi Sea were difficult to define because research addressing the impact on environmental factors offered only a snapshot and included too few cases. In addition, understanding the impact on the water mass, which is known to have the greatest influence on zooplankton communities, was further complicated by analyses of water systems using different water mass classification criteria (e.g., Matsuno et al., 2011; Questel et al., 2013; Ershova et al., 2015b; Corlett and Pickart, 2017; Pinchuk and Eisner, 2017; Xu et al., 2018; Spear et al., 2019). The characteristics of water masses flowing northward through the Bering Strait and directly affecting the occurrence of Pacific copepod species need to be clarified if we are to understand the interannual variations in Pacific zooplankton abundances in the Chukchi Sea.

In this study, we discovered the mass occurrence of Pacific copepod species in the southern Chukchi Sea in August 2015. We measured hydrographic properties using mooring systems and conductivity/temperature/depth (CTD) surveys and correlated these with the mass occurrence of Pacific copepods. This study examined whether an increase in water temperature resulted in the occurrence of Pacific copepod species in the southern
Chukchi Sea or whether the Pacific copepod species increased only in tandem with the rise of BSW water temperature. The mass occurrence of Pacific copepod species largely correlated with long-term observation data using a mooring system rather than with the "in situ" water mass examined in CTD surveys.

\section{MATERIALS AND METHODS}

\section{Zooplankton Sample Collection and Processing}

Zooplankton samples were collected in the Bering Strait and Chukchi Sea during 5-12 August in 2014, 2015, and 2016 (Figure 1). In all cases, a bongo net was towed at a speed of $60 \mathrm{~m} \mathrm{~min} \mathrm{~min}^{-1}$ for several minutes to sample the entire water column from the bottom to the surface from the IBRV Araon. The bongo net had a $330-\mu \mathrm{m}$ mesh and a mouth diameter of $60 \mathrm{~cm}$; there were 18 net hauls at 11 stations (Figure 1). Samples from the bongo net were immediately preserved with $5 \%$ neutralized formaldehyde for quantitative analyses and were identified to the lowest taxonomic level using a microscope. Abundances [individuals (indiv.) $\mathrm{m}^{-3}$ ] were calculated via the revolution counts from a one-way flowmeter mounted in the mouth of the net.

The type of zooplankton sampling gear used influences the abundance, biomass, and composition of the catch as a result of extrusion or avoidance (Skjoldal et al., 2013). When comparing zooplankton datasets, differences in sampling gear must be considered, especially the sizes of the mesh and net mouth. Traditionally, ring (or bongo, $500 \mu \mathrm{m}, 0.5-1 \mathrm{~m}$ mouth diameter), Nansen (333 $\mu \mathrm{m}, 0.7 \mathrm{~m}$ mouth diameter), or Juday $(\sim 170 \mu \mathrm{m}$, $0.37 \mathrm{~m}$ mouth diameter) nets are used (Ershova et al., 2015b). Recently, $150 \mu \mathrm{m}$ nets have been used to survey small species in Arctic research (Pinchuk and Eisner, 2017; Spear et al., 2019). Coarse mesh nets (e.g., $500 \mu \mathrm{m}$ nets) can undersample small species, which commonly make up $>90 \%$ of the total abundance in this area, while fine mesh nets $(<170 \mu \mathrm{m})$ may underrepresent the larger, faster, and rarer species (Questel et al., 2013). Therefore, we used a $330 \mu \mathrm{m}$ net (0.6 m mouth diameter), and directly compared the Pacific copepods, which are common enough to be well represented when collected with fine-mesh nets, but large enough to be captured by most coarse nets. The species abundances were generally converted into individuals (indiv.) $\mathrm{m}^{-3}$ in previous studies.

For comparison with current and historical data, the sampling grid was subdivided into two domains: Southern Chukchi (SC) south of $68^{\circ} \mathrm{N}$ and Central Chukchi (CC) north of $68^{\circ} \mathrm{N}$. The stations at $68^{\circ} \mathrm{N}$ were included in CC. The following wellknown indicator species were chosen and combined as Pacific species (Figure 2): E. bungii, M. pacifica, Neocalanus spp. (Neocalanus cristatus, Neocalanus plumchrus, and Neocalanus flemingeri). Although some of these taxa are present outside the Pacific region, this copepod group has long been recognized as dominant in waters of the Pacific Bering Sea (Hopcroft et al., 2010; Matsuno et al., 2011; Ershova et al., 2015b). MANOVA and one-way ANOVA analyses of zooplankton abundances and environmental data were performed with IBM 


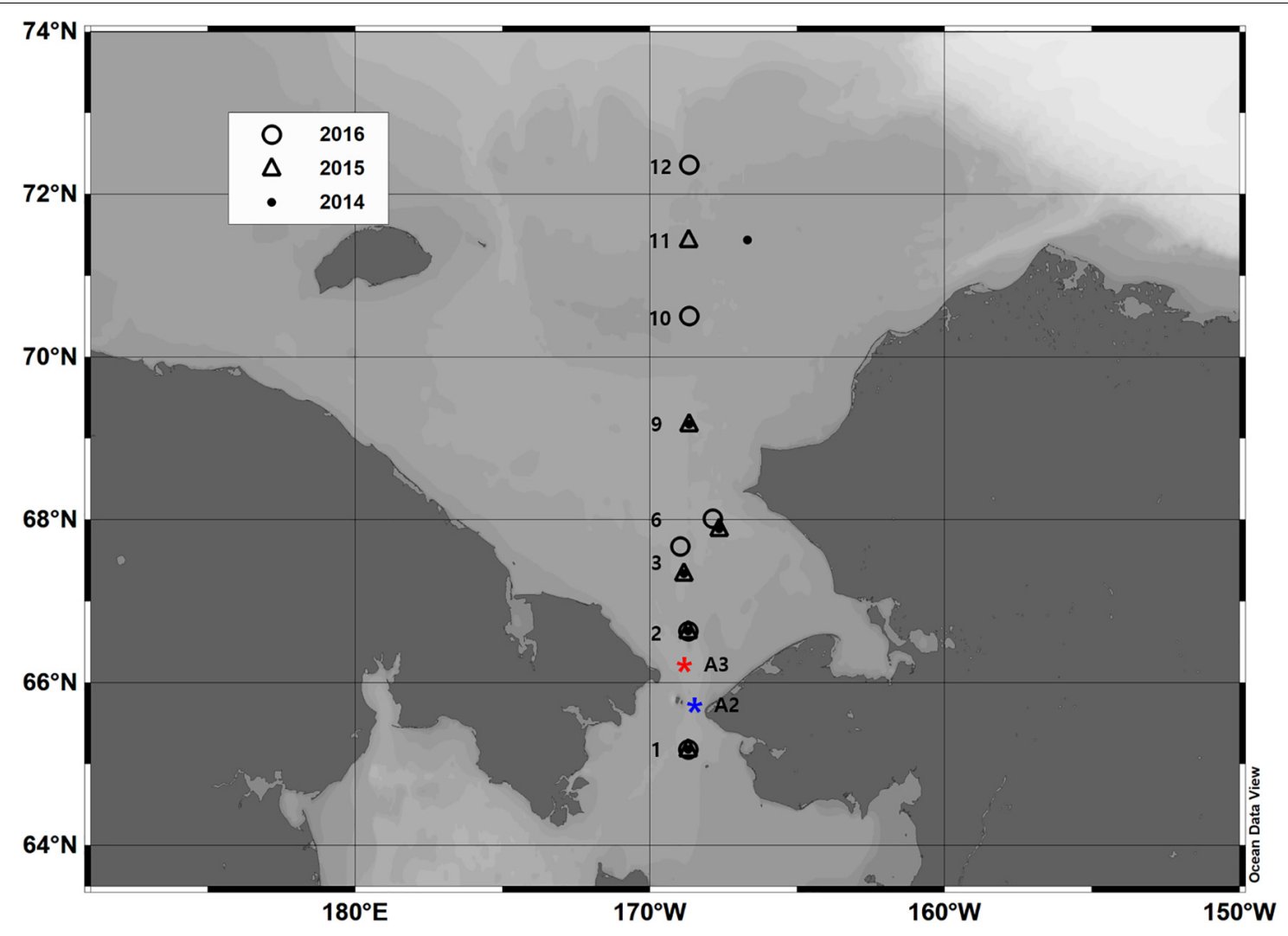

FIGURE 1 | Map of the study area with zooplankton collecting locations represented by circles (2016), squares (2015), and dots (2014). The blue asterisk is the A2 mooring location, and the red asterisk is the A3 mooring location.

SPSS v23.0. Canonical correlation analysis was used to evaluate relationships between the abundance of Pacific copepod species and environmental data using paleontological statistics (PAST) software (Hammer et al., 2001). Independent $t$-tests were used to re-evaluate relationships between the abundance of Pacific copepod species and specific water masses based on water temperature and salinity.

\section{CTD Casting and Mooring Data}

An intensive oceanographic survey was conducted at the entrance of Bering Strait and continued northward to $72.5^{\circ} \mathrm{N}$ latitude for the 3 years of the study. Along the stations, vertical profiles of temperature and salinity were obtained from the hydro-casts of a SBE32 carousel water sampler equipped with an SBE 9plus Conductivity-Temperature-Depth (CTD) profiler. For a more accurate classification of water masses inflowing through the Bering Strait, we used the water temperature and salinity data obtained from the Bering Strait Mooring Data Archive ${ }^{1}$. The water temperatures and salinities were measured by Sea-Bird CTD profilers (SBE 16plus and SBE 37) installed at the top and bottom of the mooring system at mooring sites A2 $\left(65^{\circ} 46.9^{\prime} \mathrm{N}\right.$, $\left.168^{\circ} 34.1^{\prime} \mathrm{W}\right)$ and $\mathrm{A} 3\left(66^{\circ} 19.6^{\prime} \mathrm{N} 168^{\circ} 57.5^{\prime} \mathrm{W}\right.$, Figure 1). Site A2 is located in the eastern channel of the strait, whereas Site A3

${ }^{1}$ http://psc.apl.washington.edu/BeringStrait.html is located slightly north of the strait (Figure 1). In general, the Anadyr Water via the western channel and warmer/fresher waters via the eastern channel combine at Site A3. We used a time series of temperature and salinity data available at A2 and A3 during the period of July to September in 2007, 2009, 2012, 2014,2015 , and 2016. For more details of the mooring data, please refer to Woodgate et al. (2005).

\section{Water Mass Identification}

The Chukchi Sea and Bering Strait waters are classified into two or three main water masses: Alaskan Coastal Water (ACW) and BSW (or, Bering Shelf Water and Anadyr Water) (Coachman et al., 1975; Woodgate et al., 2005; Stabeno et al., 2018). Until recently, various trends in the properties of these water masses have been reported in the Chukchi Sea (Ershova et al., 2015b; Corlett and Pickart, 2017; Danielson et al., 2017; Pickart et al., 2019). In particular, excellent analyses of water masses in this area have been performed by Pickart and colleagues (Pickart and Stossmeister, 2008; Pickart et al., 2010, 2016, 2019; Brugler et al., 2014; Gong and Pickart, 2015, 2016; Pisareva et al., 2015; Corlett and Pickart, 2017; Linders et al., 2017; Lin et al., 2019); many previous studies have cited or applied Pickart's classifications when identifying water masses (e.g., Ershova et al., 2015a; Weingartner et al., 2017; Yamashita et al., 2019). Due to the purpose and region of this study, the water masses 
A

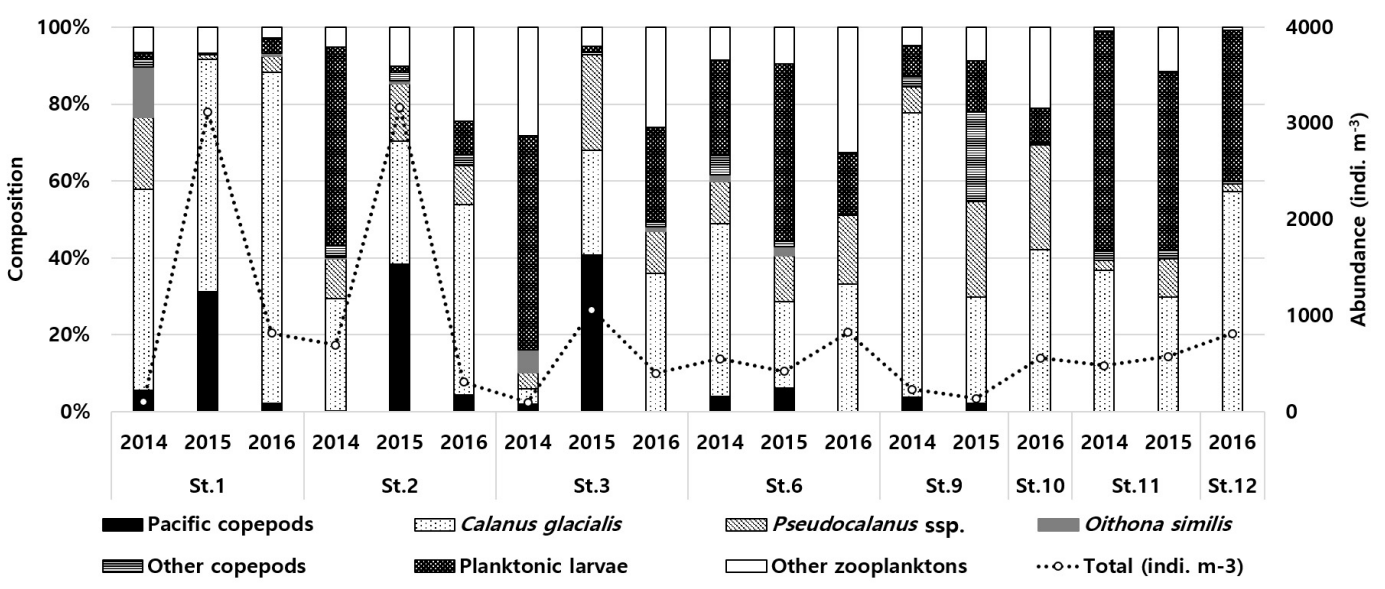

B

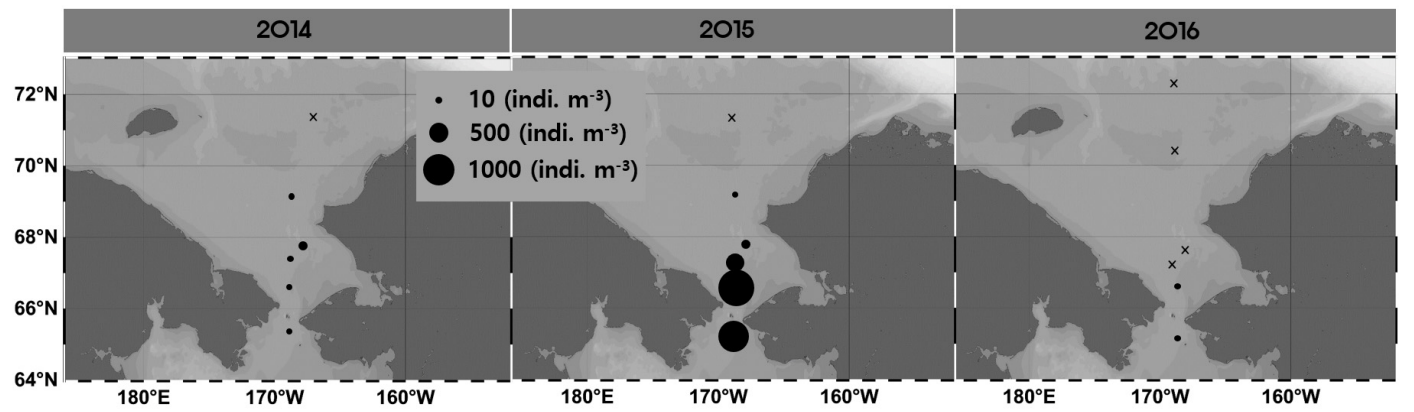

C

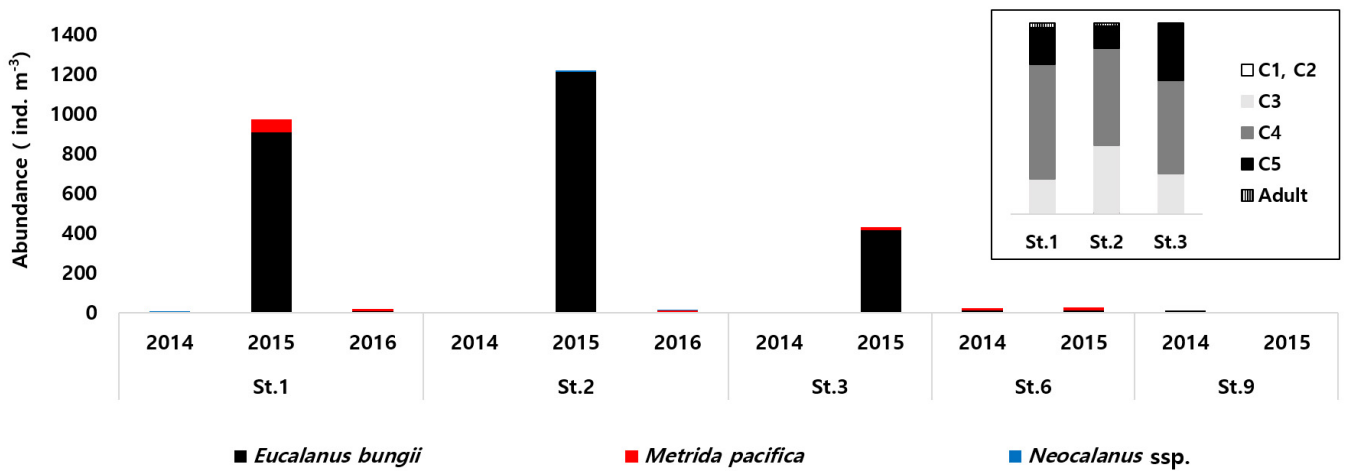

FIGURE 2 | (A) Composition of zooplankton and total abundance in summer for the Southern Chukchi Sea 2014-2016; (B) Proportional abundance plots (indiv. $\mathrm{m}^{-3}$ ) of Pacific copepods in the Chukchi Sea (Eucalanus bungii, Metridia pacifica, and Neocalanus spp. combined); (C) Composition of Pacific copepods in summer for the Southern Chukchi Sea 2014-2016.

were identified with reference to the recent and well-organized methods of classification in Corlett and Pickart (2017) and Pickart et al. (2019).

Using deep downcast data from each CTD station and data from two mooring stations, we plotted the temperature-salinity (T-S) diagram for water mass identification (Supplementary Figure S1 and Figure 3). The T-S diagram showed that the study area was occupied by several distinct water masses: ACW, Atlantic Water (AW), and BSW. However, the CTD data and the data obtained from mooring systems consisted mainly of ACW and BSW. ACW was a relatively warm and fresh water mass with high temperatures $\left(3-10^{\circ} \mathrm{C}\right)$ and a salinity range of
30-32 (Table 1). The AW water mass had high salinity ( $>33.6$, Table 1). BSW was comprised by combining Anadyr water and Bering shelf water in the Bering Strait (Coachman et al., 1975). The BSW water mass had a salinity range of 30.5-33.6 and temperature of $0-10^{\circ} \mathrm{C}$ (Corlett and Pickart, 2017; Pickart et al., 2019). One year, we observed warm BSW flowing in during the summer, which required a separate designation. Therefore, based on Pickart's water mass classification of the Chukchi Sea, BSW with a temperature $>3^{\circ} \mathrm{C}$ was referred to as high-temperature BSW ( BSW hight ) for the purposes of this study (Table 1). By contrast, $\mathrm{BSW}$ with a temperature $\leq 3^{\circ} \mathrm{C}$ is referred to here as

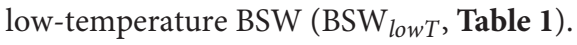


TABLE 1 | Summary of southern Chukchi Sea water mass characteristics.

\begin{tabular}{lccc}
\hline \multicolumn{1}{c}{ Water mass } & Temperature $\left({ }^{\circ} \mathbf{C}\right)$ & Salinity \\
\hline Alaskan Coastal Water (ACW) & $>3$ & $30-32$ \\
Atlantic Water (AW) & $>-1.26$ & $>33.6$ \\
Bering Summer Water (BSW) & & $>0$ & $30-33.6$ \\
& BSW $_{\text {hight }}$ & $>3$ & $32-33.6$ \\
& BSW $_{\text {low }}$ & $0-3$ & $30-33.6$ \\
\hline
\end{tabular}

\section{RESULTS}

\section{Zooplankton Abundance}

Zooplankton abundance ranged from 99 to 3,168 indiv. $\mathrm{m}^{-3}$ (mean: 799 indiv. $\mathrm{m}^{-3}$ ), with the abundance in the southern Chukchi Sea being higher than that in the north, especially in 2015 (Figure 2A). Copepods comprised 16-93\% (mean: 65\%) of zooplankton abundance, and plankton larvae comprised 055\% (mean: 23\%) of abundance. The most dominant species was Calanus glacialis, which ranged from 4 to 1,732 indiv. $\mathrm{m}^{-3}$ (mean: 178 indiv. $\mathrm{m}^{-3}$, Figure 2A). The highest total zooplankton abundance $\left(3,168\right.$ indiv. $\left.\mathrm{m}^{-3}\right)$ was recorded in the southern Chukchi (SC) Sea in 2015 (mean: 2447 indiv. $\mathrm{m}^{-3}$, Table 2). Pacific copepod species accounted for a maximum of $40 \%$ of the total zooplankton abundance in the southern Chukchi Sea (Figure 2A). Particularly, at St. 2 (Figure 1) in 2015, more than 1,000 indiv. $\mathrm{m}^{-3}$ of Pacific copepod species appeared (mean in SC: 874 indiv. $\mathrm{m}^{-3}$, Table 2), with a range of $0-1,210$ indiv. $\mathrm{m}^{-3}$ (Figures $2 \mathrm{~B}, \mathbf{C}$ ), and E. bungii contributed significantly to the Pacific copepod species abundance (mean in SC: 843 indiv. $\mathrm{m}^{-3}, p<0.001$, Figure $2 \mathrm{C}$ and Table 2 ). And, the majority of these pacific copepod species were late-stage copepodites of $\mathrm{C} 4$ and C5 (Figure 2C).

\section{Water Masses and Pacific Copepod Species}

In situ CTD data showed that in 2015, when Pacific copepod species were collected in abundance, showed an inflow of BSW $_{\text {hight }}$ (Supplementary Figure S1). However, due to the high variability of water temperature and salinity, there was no statistically significant correlation between the CTD and the biological data $(p>0.05)$. We obtained additional long-term physical data from the mooring systems (A2, A3) in the Bering Strait (Figure 1). In these mooring systems, long-term water temperature and salinity data were obtained for approximately 20 days, including observations at the times of zooplankton collections in 2014-2016. The T-S diagram from the mooring data (Figure 3 ) shows that the properties of the water masses in this region were based on the Pacific summer waters, ACW, and BSW. In particular, the data from the A3 mooring, located near St. 2 (Figure 1), where Pacific copepod species occurred, consisted mainly of BSW throughout the study period. In 2015, when the Pacific copepod species appeared in abundance, the water temperatures and salinities were relatively high $(p<0.001)$; of particular note, the temperature of BSW was $>3^{\circ} \mathrm{C}$ (Figure 4A). On the other hand, relatively cold BSW waters $\left(<3^{\circ} \mathrm{C}\right)$ were transported into the Bering Strait in 2014 and 2016 (Figure 4A). Particularly in 2014, a large amount of ACW, which has high temperatures $\left(3.5-6.5^{\circ} \mathrm{C}\right)$, was transported, but Pacific copepod species rarely appeared (Figure 4). The mean water temperatures in Figure 4A show that the BSW, which was warmer than $3^{\circ} \mathrm{C}$, was transported into the southern Chukchi Sea in 2015 when the Pacific copepod species were abundant. On the other hand, the BSW waters cooler than $3^{\circ} \mathrm{C}$ were transported in 2014 and 2016 when the Pacific copepod species were almost absent.

\section{DISCUSSION}

Like the Arctic Ocean, the Chukchi Sea exhibits a predominance of copepods in terms of zooplankton abundance and biomass (Kosobokova and Hopcroft, 2010; Ershova et al., 2015b; Smoot and Hopcroft, 2017; Carstensen et al., 2019; Kasyan, 2020), although larvaceans and meroplankton also contribute to the abundance and biomass of the zooplankton community during summer (Lane et al., 2008; Matsuno et al., 2016). Among the copepods, the zooplankton surveys conducted in 2015 showed a notable increase in Pacific copepod species in the southern Chukchi Sea. We focused on the relationship between the occurrence of Pacific copepod species and water masses to elucidate the cause. Several previous studies have shown that BSW is one of the most common water masses during summer in the Bering Strait and in the Chukchi Sea (Ershova et al., 2015b; Corlett and Pickart, 2017; Danielson et al., 2017; Stabeno et al., 2018). The large Pacific copepods M. pacifica, Neocalanus spp., and E. bungii are the dominant species in BSW (Ershova et al., 2015b; Pinchuk and Eisner, 2017).

During 2014-2016, a large amount of BSW inflow occurred every year (Figure 3), but the Pacific copepod species appeared in high abundance only in 2015. This means that the occurrence of Pacific copepod species in the southern Chukchi Sea cannot be explained simply by the inflow of BSW. The mass occurrence of Pacific copepod species could be the result of an immediate water mass change, but it could also be the result of the longterm inflow of the water mass. Thus, we analyzed long-term water temperature and salinity data from the mooring systems. The results showed that Pacific copepod species appeared in the Bering Strait and the southern Chukchi Sea when relatively warm $\left(>3^{\circ} \mathrm{C}\right)$ BSW was transported (Figure 4). The ACW is relatively dense and flows surface, whereas the high-density BSW flows bottom; therefore, the difference is more apparent when considering the bottom portions of mooring data (Figure 3B). In 2014 and 2016, when there were few Pacific copepod species, BSW $_{\text {hight }}$ was rarely encountered (Figures 3, 4A). There have also been few reports of BSW $\mathrm{BighT}_{\mathrm{T}}$ in many studies of the water mass in the Chukchi Sea (Corlett and Pickart, 2017; Pickart et al., 2019). Specifically, in 2014, a large influx of warm ACW (3.5$6.5^{\circ} \mathrm{C}$, Figures $3 \mathrm{~A}, \mathbf{4 A}$ ) did not cause the occurrence of Pacific Copepod species. The abundance of E. bungii, in particular, was strongly positively correlated with high temperature and high salinity (canonical correlation: $r=0.74 ; p<0.001$ ). It was also significantly related $(p<0.001)$ with $\mathrm{BSW}_{h i g h T}$, with a high temperature $\left(>3^{\circ} \mathrm{C}\right)$ and high salinity (32-33.6). In addition, 
TABLE 2 | Summary of mean abundance (indiv. $\mathrm{m}^{-3}$ ) \pm SD for dominant taxa in southern Chukchi Sea (SC) and central Chukchi Sea (CC).

\begin{tabular}{|c|c|c|c|c|c|c|c|}
\hline & \multirow{3}{*}{ Taxon } & \multicolumn{6}{|c|}{ Abundance (indiv. $\mathrm{m}^{-3}$ ) $\pm \mathrm{SD}$} \\
\hline & & \multicolumn{2}{|c|}{2014} & \multicolumn{2}{|c|}{2015} & \multicolumn{2}{|c|}{2016} \\
\hline & & SC & $\mathrm{CC}$ & SC & $\mathrm{cc}$ & sc & $\mathrm{CC}$ \\
\hline \multirow[t]{6}{*}{ Pacific copepods } & Eucalanus bungii & $3.00 \pm 1.41$ & $6.33 \pm 4.50$ & $843.33 \pm 327.97^{\star \star}$ & $5.00 \pm 5.10$ & $2.91 \pm 2.70$ & - \\
\hline & Metridia pacifica & - & $4.00 \pm 5.66$ & $28.33 \pm 28.89$ & $4.67 \pm 6.60$ & $6.76 \pm 4.89$ & - \\
\hline & Neocalanus spp. & $0.33 \pm 0.47$ & - & $2.33 \pm 3.30$ & - & $0.74 \pm 1.05$ & - \\
\hline & Calanus glacialis & $87.33 \pm 83.81$ & $198.67 \pm 34.24$ & $1060.33 \pm 650.50^{*}$ & $101.00 \pm 54.52$ & $332.89 \pm 260.90$ & $325.41 \pm 101.17$ \\
\hline & Pseudocalanus spp. & $31.67 \pm 28.57$ & $29.33 \pm 21.75$ & $258.00 \pm 177.20$ & $47.00 \pm 9.63$ & $36.50 \pm 5.64$ & $105.65 \pm 63.32$ \\
\hline & Oithona similis & $7.67 \pm 4.64$ & $3.33 \pm 4.71$ & $8.67 \pm 12.26$ & $3.33 \pm 4.71$ & $3.65 \pm 2.72$ & - \\
\hline \multirow[t]{4}{*}{ Other copepods } & Acartia longiremis & $6.33 \pm 8.26$ & $11.00 \pm 5.72$ & $28.67 \pm 30.65$ & $15.67 \pm 12.12$ & $5.17 \pm 3.77$ & $1.63 \pm 2.31$ \\
\hline & Calanus hyperboreus & - & $2.33 \pm 3.30$ & - & - & - & - \\
\hline & Centropages abdominalis & $2.00 \pm 2.16$ & $1.33 \pm 0.94$ & - & $1.00 \pm 1.41$ & - & - \\
\hline & Metridia longa & - & - & - & - & - & $2.15 \pm 3.04$ \\
\hline \multirow[t]{5}{*}{ Planktonic larvae } & Cirriped larvae & $134.67 \pm 153.21$ & $130.00 \pm 103.83$ & $14.33 \pm 10.78$ & $119.33 \pm 92.34$ & $36.31 \pm 35.74$ & $147.00 \pm 100.00$ \\
\hline & Decapoda larvae & - & - & - & - & $2.02 \pm 0.28^{\star \star}$ & - \\
\hline & Gastropoda larvae & - & $3.00 \pm 2.16^{\star *}$ & - & - & - & - \\
\hline & Ophiopluteus larvae & $1.67 \pm 2.36$ & $2.33 \pm 1.70$ & - & $28.67 \pm 36.38$ & - & $2.38 \pm 1.71$ \\
\hline & Polychaeta larvae & $1.33 \pm 0.94$ & $8.33 \pm 9.74$ & $6.67 \pm 9.43$ & $11.67 \pm 14.43$ & $13.85 \pm 8.67$ & $17.80 \pm 15.95$ \\
\hline \multirow[t]{6}{*}{ Other zooplankton } & Unidentified Cnidaria & $1.33 \pm 0.94$ & - & $4.00 \pm 5.66$ & $3.33 \pm 2.87$ & $4.04 \pm 3.66$ & $8.59 \pm 4.71$ \\
\hline & Sagitta spp. & $4.00 \pm 4.97$ & $2.33 \pm 3.30$ & $28.33 \pm 19.26$ & $10.00 \pm 4.97$ & $24.12 \pm 17.63$ & $10.22 \pm 6.89$ \\
\hline & Oikopleura spp. & $13.00 \pm 7.12$ & $9.33 \pm 9.88$ & $38.67 \pm 50.50$ & $24.00 \pm 20.02$ & $29.50 \pm 16.48$ & $112.71 \pm 106.12$ \\
\hline & Unidentified Amphipoda & $0.67 \pm 0.47$ & $0.33 \pm 0.47$ & $9.67 \pm 13.67$ & - & - & - \\
\hline & Unidentified Euphausiacea & $4.67 \pm 1.89$ & $9.00 \pm 10.03$ & $115.67 \pm 82.64^{\star}$ & $2.00 \pm 1.41$ & $9.75 \pm 5.67$ & - \\
\hline & Total & $299.67 \pm 278.15$ & $421.00 \pm 135.97$ & $2447.00 \pm 981.71^{\star}$ & $376.67 \pm 180.61$ & $508.20 \pm 220.75$ & $733.55 \pm 124.01$ \\
\hline \multicolumn{2}{|c|}{ Carbon content $\left(\mathrm{mg} / \mathrm{m}^{-3}\right)$} & $19.65 \pm 9.15$ & $22.39 \pm 7.76$ & $308.82 \pm 169.99^{*}$ & $23.44 \pm 13.77$ & $61.27 \pm 25.92$ & $40.09 \pm 21.80$ \\
\hline
\end{tabular}

Asterisk $\left(^{*}\right)$ indicates significant difference $\left({ }^{*} p<0.05\right.$; $\left.{ }^{* *} p<0.001\right)$. 
A

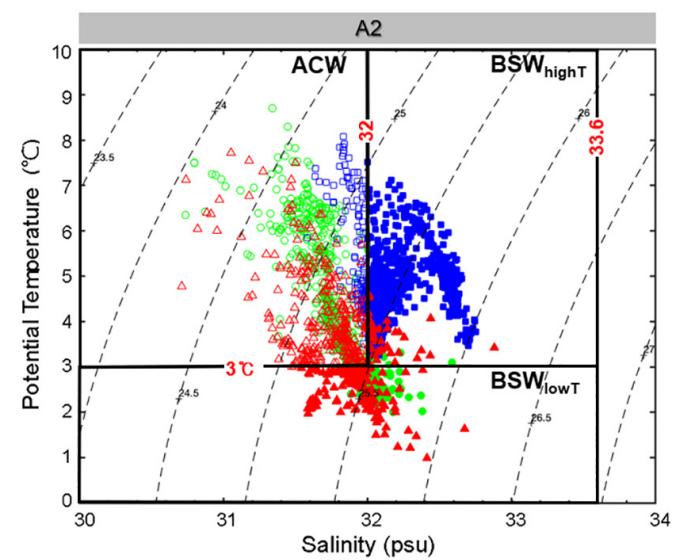

B

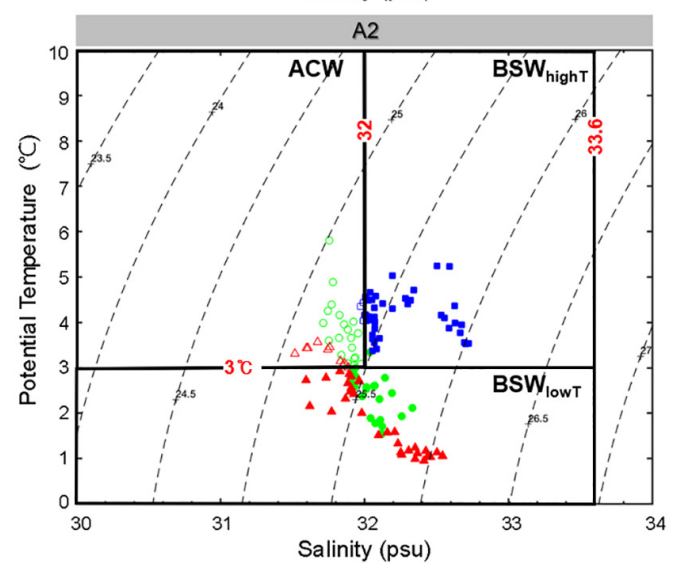

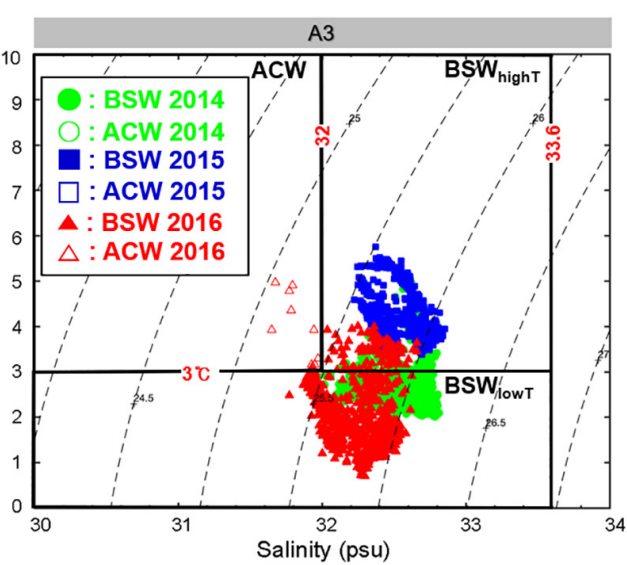

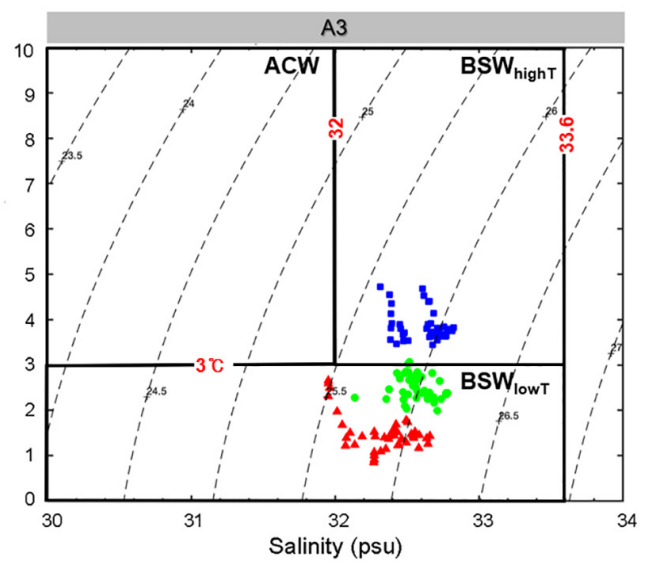

FIGURE 3 | A2 and A3 mooring T-S Diagram for 20 July-10. August 2014-2016 (A) Surface (B) Bottom. The shapes filled with color are BSW, and the shapes with no color are ACW (Green circles: 2014; Blue squares: 2015; Red triangles: 2016).

long-term mooring data (for 3 weeks) showed that the BSW hight, which is more pronounced than in the CTD data, continued to mainly flow in 2015 (Figure 3).

The subarctic Pacific Ocean and the Arctic Ocean have very different zooplankton compositions (Pomerleau et al., 2014; Matsuno et al., 2016). E. bungii, M. pacifica, and Neocalanus spp. are the dominant plankton copepods in the Bering Sea area of the subarctic Pacific Ocean (Springer et al., 1989; Ershova et al., 2015b). In recent years, zooplankton communities in the Chukchi Sea have become increasingly influenced by BeringPacific fauna (Ershova et al., 2015b). In 2015 of the present study, however, the mass occurrence of Pacific copepods in the southern Chukchi Sea was exceptional (Supplementary Table S1 and Supplementary Figure S2). In particular, previous studies have not observed massive occurrences of the large copepod E. bungii at more than 1000 indiv. $\mathrm{m}^{-3}$ (Shoden et al., 2005; Ershova et al., 2015a,b). Here, we discovered that E. bungii occurred in this region as the temperature of the BSW rose. Since there were relatively high levels of copepodites (Figure 2C), they

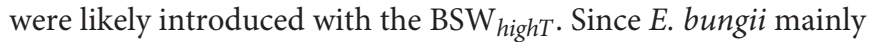
inhabits the warm North Pacific region, it is well suited to warm environments. In previous reports, the abundance of $E$. bungii also had a higher correlation with water temperature among
Pacific copepods (Ershova et al., 2015b). Notably, planktonic larvae increased in 2014 when the temperature of the ACW was high (Figure 2A). This is consistent with previous studies showing that ACW is dominated by meroplankton (Ershova et al., 2015b). Thus, the effect of rising water temperatures exhibits an extremely high variability, but the result might be an increase in the preponderance of certain species and ultimately, decreased species diversity in the Chukchi Sea.

In the surface mooring data of the T-S diagram (Figure 3A), it is difficult to distinguish pure BSW, due to the mixing of the relatively low-density ACW and relatively high-density BSW. In some studies, the two water masses (ACW and BSW) and their mixed water mass have been defined separately for this reason (Ershova et al., 2015b; Pinchuk and Eisner, 2017). By these standards, the occurrence of Pacific copepod species was related not only to the temperature of the BSW but also to that of the mixed water mass containing BSW. However, even if we define mixed water masses (e.g., ACW/BSW) to eliminate the boundary ambiguity caused by the mixing of these water masses, the boundaries will become blurred again, resulting in further ambiguity. Therefore, it is considered more important to use a water mass classification system with clear boundaries that are commonly used and defined by experts in the study area. 
A
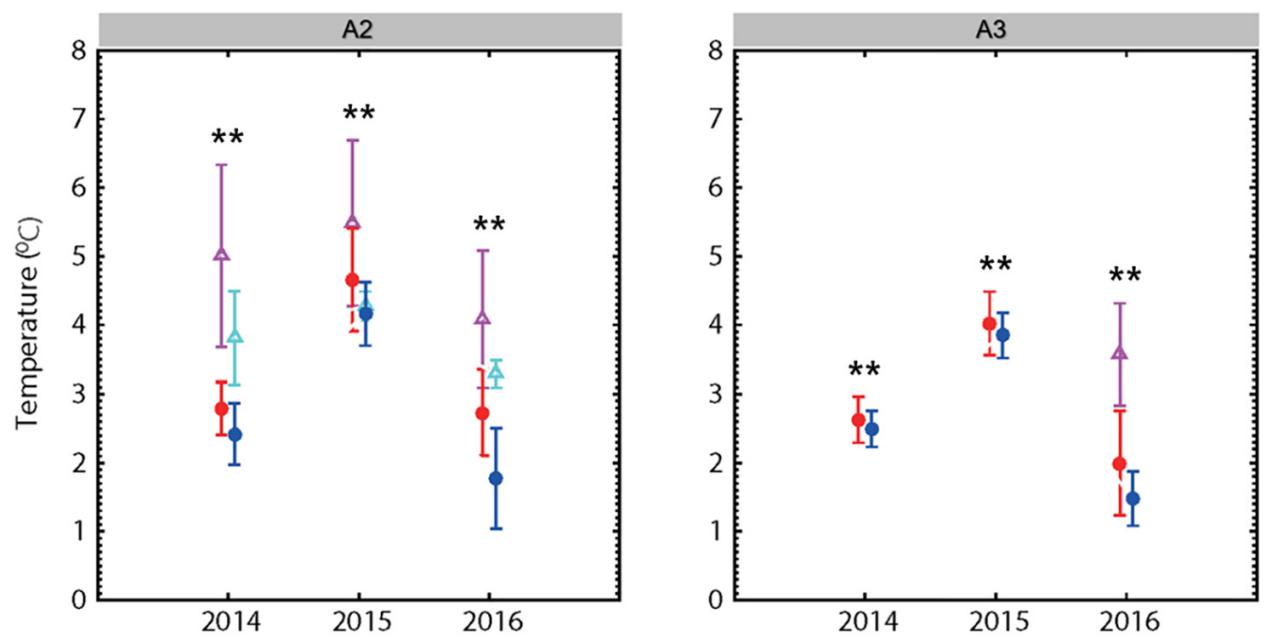

B
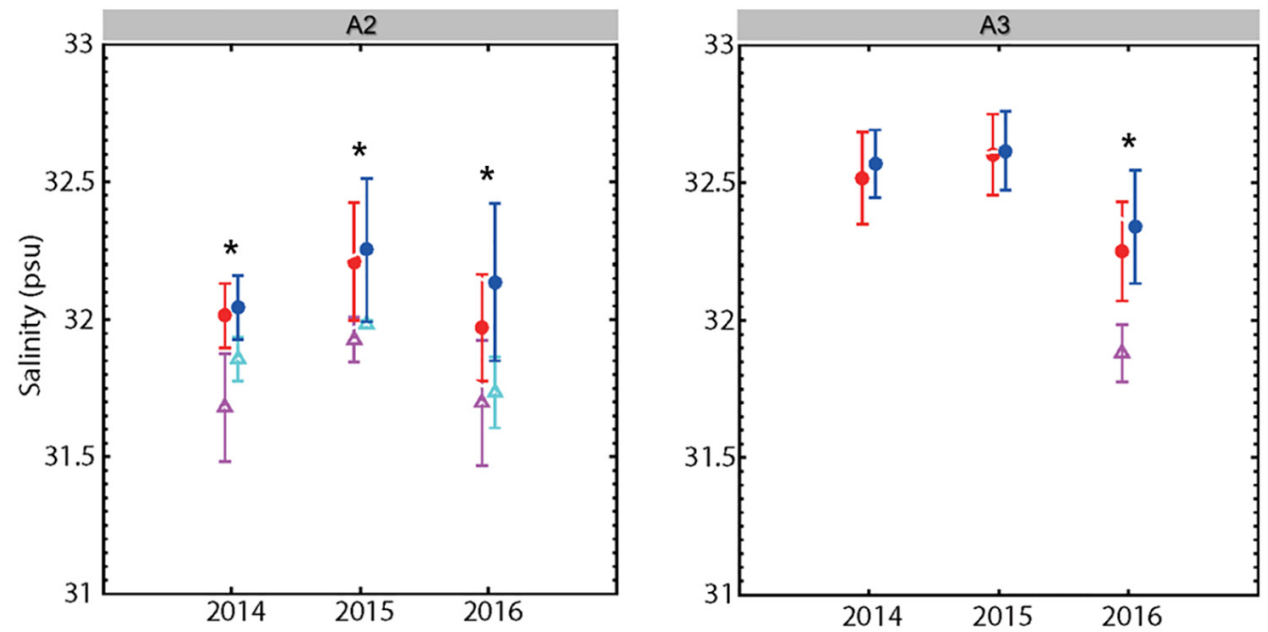

C
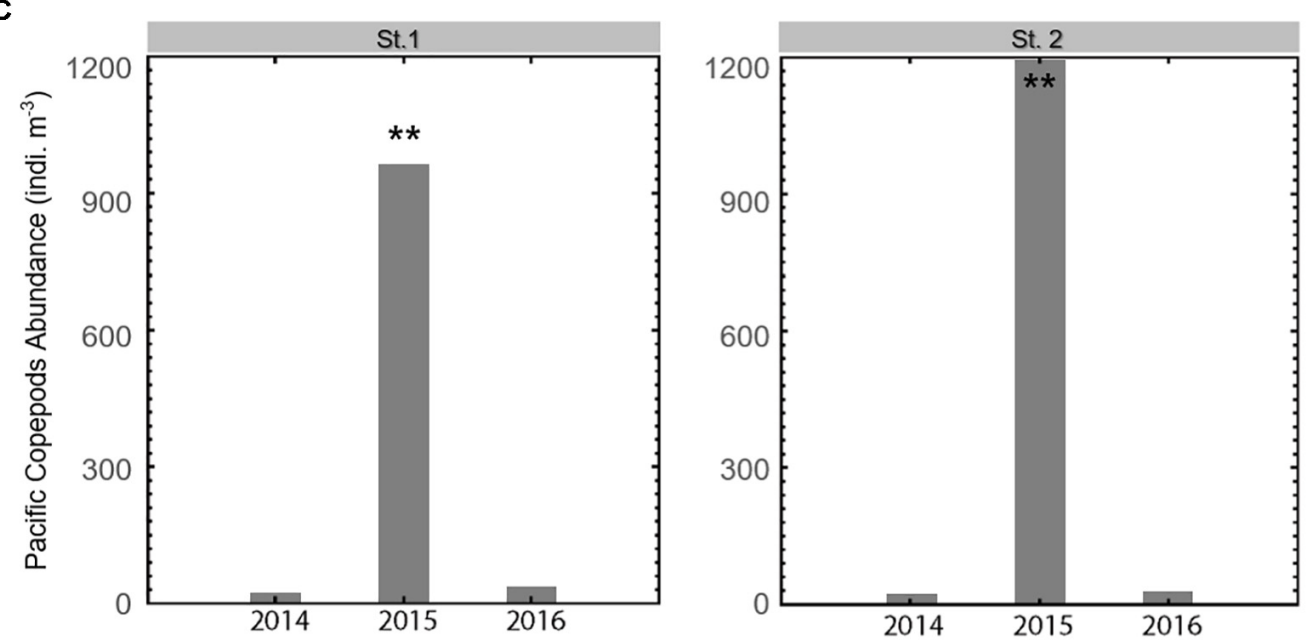

FIGURE 4 | (A) A2 and A3 mooring mean temperature for 20 July - 10. August 2014-2016. Asterisk ( $\left.{ }^{*}\right)$ indicates significant difference $\left({ }^{*} p<0.05 ;{ }^{* *} p<0.001\right)$; (B) A2 and A3 mooring mean salinity for 20 July - 10. August 2014-2016 (Red circles: BSW surface; Blue circles: BSW bottom; mauve triangles: ACW surface; cyan triangles: ACW bottom); (C) St. 1 and St. 2 abundance of Pacific copepods (indiv. $\mathrm{m}^{-3}$ ). 

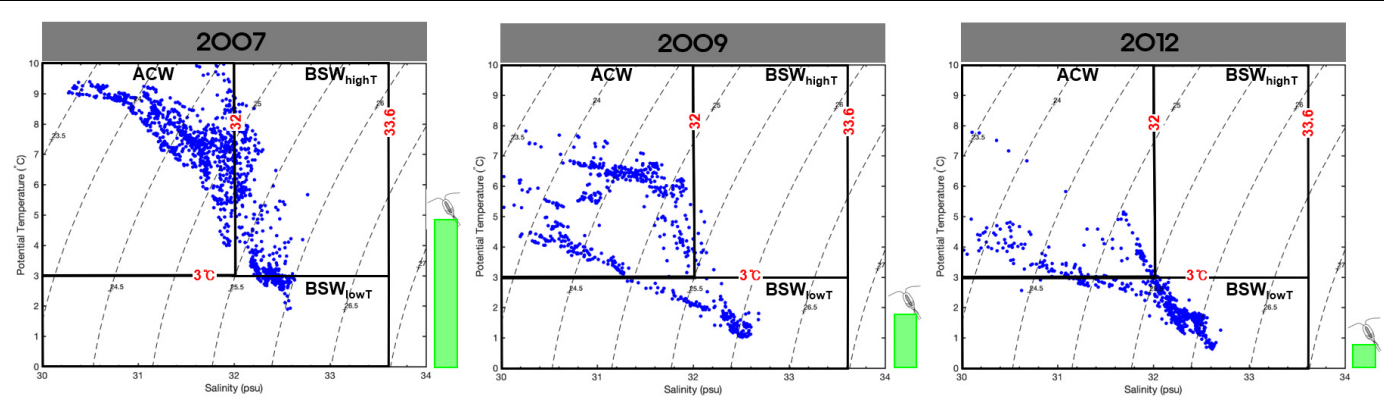

FIGURE 5 | A2 mooring T-S Diagram for September 2007, 2009, and 2012. The green bars are relative abundance of Pacific copepods.

We also looked at previous data in addition to our 3-year dataset to further validate our results. A previous study of zooplankton in the Bering Strait and the Chukchi Sea over the past 30 years revealed abundant Pacific copepod species in August and September of 2007 (Matsuno et al., 2011). In addition, recent studies have found few Pacific copepod species in September of 2009 and 2012 (Ershova et al., 2015a). Therefore, we analyzed the water masses from these 3 years using the mooring data. These data (Figure 5) showed that $\mathrm{BSW}_{\text {hight }}$ was transported in September 2007, when the Pacific copepod species appeared in abundance (408 indiv. $\mathrm{m}^{-3}$; approximately $15 \%$ of the total zooplankton composition), and the BSW temperature was low $\left(<3^{\circ} \mathrm{C}\right)$ in September 2009 and 2012, when Pacific copepod species were rarely found (Supplementary Table S1). In these reports, E. bungii and M. pacifica also showed high correlations with $\mathrm{BSW}_{\text {highT }}(p<0.05)$. Thus, the past and present data indicated that the mass occurrence of Pacific copepod species was related to the inflow of the $\mathrm{BSW}_{\text {high }}$.

In 2015, when Pacific copepod species occurred massively, there was primarily inflow of BSW $\mathrm{highT}_{\text {f }}$ for 3 weeks (Figure 3). In comparison, the water temperature was higher in 2007 than in 2015, but the BSW $_{\text {hight }}$ was not continuously present for 3 weeks (Figure 5). This shows that the mass occurrence of Pacific copepod species can occur in the southern Chukchi Sea when the BSW $\mathrm{BighT}_{\text {T }}$ continuously and exclusively flows in. Although the relationship between the BSW $\mathrm{BighT}_{\text {Th }}$ and the Pacific copepod species was significant in our study period, the water masses flowing through the Bering Strait showed high seasonal variability (Woodgate, 2018). The distributions of zooplankton also depend on season and time and are even affected by the vertical distribution of water masses (La et al., 2018). Our results cannot be generalized to all of these environments; however, our data reconfirmed the relationship between the occurrence of Pacific copepod species and the BSW in the southern Chukchi Sea (Ershova et al., 2015b). Furthermore, we found that the influx of BSW $_{\text {hight }}$ could lead to the mass occurrence of Pacific copepod species, which we revalidated using data from previous studies (Figure 5 and Supplementary Table S1). Recently, planktonic communities of the Chukchi Sea have experienced climaterelated changes through both shifts in the transport rate and penetration of Pacific copepod species into the Arctic Ocean (Hopcroft et al., 2010; Ershova et al., 2015b).
Previous data showed that the success of the Pacific copepod species was largely correlated with water temperature, so increases in the abundance of these species with future warming are expected (Ershova et al., 2015b). However, in the present data, only an increase in the temperature of BSW led to an increase in Pacific species, while an increase in the temperature of the ACW had no effect. These findings suggest that if oceanographic changes such as warming and increased BSW inflows continue in the Chukchi Sea, the mesozooplankton community could become more volatile and less diverse, with an increased population of Pacific copepod species. However, if other water masses flow in, in addition to the rise in temperature, an increase in meroplankton may be likely. In previous studies and the present one, the summer zooplankton communities of the southern Chukchi Sea have been primarily pacific in character; warming is more likely to produce greater seasonal and interannual variability than simply accelerating the Pacific character. Despite this high variability, future warming will lead to increased zooplankton biomass via the influx of large copepods and large-scale occurrence of meroplankton in the southern Chukchi Sea, which may lead to increasing number of predators, such as foraging fish (Pinchuk and Eisner, 2017; Eisner et al., 2018). As each temperature rise in the water mass is important, future studies need to observe long-term data and analyze changes in the incoming water mass separately, to understand the zooplankton communities in the Chukchi Sea better. These results will provide a baseline for assessing the effects of future water mass changes on the pelagic ecosystem of the changing Arctic Ocean.

\section{DATA AVAILABILITY STATEMENT}

The raw data supporting the conclusions of this article will be made available by the authors, without undue reservation.

\section{AUTHOR CONTRIBUTIONS}

EY conceived the study. J-HK collected the zooplankton samples. J-HK and K-HC analyzed the physical data. HL, EC, KM, S-HK, and WK contributed to the study design and data discussion. J-HK, K-HC, and EY wrote the manuscript. All authors read and approved the final manuscript. 


\section{FUNDING}

This research was a part of the project titled "Korea-Arctic Ocean Observing System (K-AOOS, KOPRI, 20160245)” funded by the MOF, Korea.

\section{ACKNOWLEDGMENTS}

The authors thank the captain and crew of the IBRV ARAON who were most helpful in all shipboard operations.

\section{REFERENCES}

Brugler, E. T., Pickart, R. S., Moore, G., Roberts, S., Weingartner, T. J., and Statscewich, H. (2014). Seasonal to interannual variability of the Pacific water boundary current in the Beaufort Sea. Prog. Oceanogr. 127, 1-20. doi: 10.1016/ j.pocean.2014.05.002

Carstensen, J., Olszewska, A., and Kwasniewski, S. (2019). Summer mesozooplankton biomass distribution in the West Spitsbergen current (2001-2014). Front. Mar. Sci. 6:202. doi: 10.3389/fmars.2019.00202

Coachman, L. K., Coachman, L. K., Aagaard, K., and Tripp, R. (1975). Bering Strait: the Regional Physical Oceanography. Washington, DC: University of Washington Press.

Corlett, W. B., and Pickart, R. S. (2017). The Chukchi slope current. Prog. Oceanogr. 153, 50-65. doi: 10.1016/j.pocean.2017.04.005

Danielson, S. L., Eisner, L., Ladd, C., Mordy, C., Sousa, L., and Weingartner, T. J. (2017). A comparison between late summer 2012 and 2013 water masses, macronutrients, and phytoplankton standing crops in the northern Bering and Chukchi Seas. Deep Sea Res. Part II Top. Stud. Oceanogr. 135, 7-26. doi: 10.1016/j.dsr2.2016.05.024

Eisner, L., Hillgruber, N., Martinson, E., and Maselko, J. (2013). Pelagic fish and zooplankton species assemblages in relation to water mass characteristics in the northern Bering and southeast Chukchi seas. Polar Biol. 36, 87-113. doi: 10.1007/s00300-012-1241-0

Eisner, L. B., Pinchuk, A. I., Kimmel, D. G., Mier, K. L., Harpold, C. E., and Siddon, E. C. (2018). Seasonal, interannual, and spatial patterns of community composition over the eastern Bering Sea shelf in cold years. Part I Zooplank. ICES J. Mar. Sci. 75, 72-86. doi: 10.1093/icesjms/fsx156

Ershova, E. A., Hopcroft, R. R., and Kosobokova, K. N. (2015a). Interannual variability of summer mesozooplankton communities of the western Chukchi Sea: 2004-2012. Polar Biol. 38, 1461-1481. doi: 10.1007/s00300-0151709-9

Ershova, E. A., Hopcroft, R. R., Kosobokova, K. N., Matsuno, K., Nelson, R. J., Yamaguchi, A., et al. (2015b). Long-term changes in summer zooplankton communities of the western Chukchi Sea, 1945-2012. Oceanography 28, 100115. doi: $10.5670 /$ oceanog. 2015.60

Gong, D., and Pickart, R. S. (2015). Summertime circulation in the eastern Chukchi Sea. Deep Sea Res. Part II Top. Stud. Oceanogr. 118, 18-31. doi: 10.1016/j.dsr2. 2015.02.006

Gong, D., and Pickart, R. S. (2016). Early summer water mass transformation in the eastern Chukchi Sea. Deep Sea Res. Part II Top. Stud. Oceanogr. 130, 43-55. doi: $10.1016 /$ j.dsr2.2016.04.015

Hammer, $\varnothing$, Harper, D. A., and Ryan, P. D. (2001). PAST: paleontological statistics software package for education and data analysis. Palaeontol. Electron. 4:9.

Hopcroft, R. R., Kosobokova, K. N., and Pinchuk, A. I. (2010). Zooplankton community patterns in the Chukchi Sea during summer 2004. Deep Sea Res. Part II Top. Stud. Oceanogr. 57, 27-39. doi: 10.1016/j.dsr2.2009. 08.003

Kasyan, V. V. (2020). Variability and spatial distribution of zooplankton communities in the western Chukchi Sea during early fall. Polar Sci. 24:100508. doi: 10.1016/j.polar.2020.100508

Kosobokova, K. N., and Hopcroft, R. R. (2010). Diversity and vertical distribution of mesozooplankton in the Arctic's Canada Basin. Deep Sea Res. Part II Top. Stud. Oceanogr. 57, 96-110. doi: 10.1016/j.dsr2.2009.08.009

\section{SUPPLEMENTARY MATERIAL}

The Supplementary Material for this article can be found online at: https://www.frontiersin.org/articles/10.3389/fmars. 2020.00612/full\#supplementary-material

FIGURE S1 | T-S Diagram of CTD (Bottom to Top) for the Southern Chukchi Sea 2014-2016.

FIGURE S2 | Pacific copepod species abundance in the Chukchi Sea after 1946 Each white symbol represents previous cruise, the red one represents the present study in 2015. The dashed line shows a fitted linear trend over averaged data.

La, H. S., Shimada, K., Yang, E. J., Cho, K.-H., Ha, S.-Y., Jung, J., et al. (2018) Further evidence of diel vertical migration of copepods under Arctic sea ice during summer. Mar. Ecol. Prog. Ser. 592, 283-289. doi: 10.3354/meps12484

Lane, P. V., Llinás, L., Smith, S. L., and Pilz, D. (2008). Zooplankton distribution in the western Arctic during summer 2002: hydrographic habitats and implications for food chain dynamics. J. Mar. Syst. 70, 97-133. doi: 10.1016/ j.jmarsys.2007.04.001

Lin, P., Pickart, R. S., McRaven, L. T., Arrigo, K. R., Bahr, F., Lowry, K. E., et al. (2019). Water mass evolution and circulation of the northeastern Chukchi Sea in summer: implications for nutrient distributions. J. Geophys. Res. Oceans 124, 4416-4432. doi: 10.1029/2019jc015185

Linders, J., Pickart, R. S., Björk, G., and Moore, G. (2017). On the nature and origin of water masses in Herald Canyon, Chukchi Sea: synoptic surveys in summer 2004, 2008, and 2009. Prog. Oceanogr. 159, 99-114. doi: 10.1016/j.pocean.2017. 09.005

Matsuno, K., Sanchez, J. M. L., Yamaguchi, A., Hirawake, T., and Kikuchi, T. (2016). Spatial and geographical changes in the mesozooplankton community in the Bering and Chukchi Seas during the summers of 2007 and 2008. Polar Sci. 10, 335-345. doi: 10.1016/j.polar.2016.04.006

Matsuno, K., Yamaguchi, A., Hirawake, T., and Imai, I. (2011). Year-to-year changes of the mesozooplankton community in the Chukchi Sea during summers of 1991, 1992 and 2007, 2008. Polar Biol. 34, 1349-1360. doi: 10.1007/ s00300-011-0988-Z

Nelson, R., Carmack, E., McLaughlin, F., and Cooper, G. (2009). Penetration of Pacific zooplankton into the western Arctic Ocean tracked with molecular population genetics. Mar. Ecol. Prog. Ser. 381, 129-138. doi: 10.3354/ meps07940

Pickart, R. S., Moore, G., Mao, C., Bahr, F., Nobre, C., and Weingartner, T. J. (2016). Circulation of winter water on the Chukchi shelf in early Summer. Deep Sea Res. Part II Top. Stud. Oceanogr. 130, 56-75. doi: 10.1016/j.dsr2.2016.05.001

Pickart, R. S., Nobre, C., Lin, P., Arrigo, K. R., Ashjian, C. J., Berchok, C., et al. (2019). Seasonal to mesoscale variability of water masses and atmospheric conditions in Barrow Canyon, Chukchi Sea. Deep Sea Res. Part II Top. Stud. Oceanogr. 162, 32-49. doi: 10.1016/j.dsr2.2019.02.003

Pickart, R. S., Pratt, L. J., Torres, D. J., Whitledge, T. E., Proshutinsky, A. Y., Aagaard, K., et al. (2010). Evolution and dynamics of the flow through herald canyon in the western Chukchi Sea. Deep Sea Res. Part II Top. Stud. Oceanogr. 57, 5-26. doi: 10.1016/j.dsr2.2009.08.002

Pickart, R. S., and Stossmeister, G. (2008). Outflow of pacific water from the Chukchi Sea to the Arctic Ocean. Chin. J. Polar Oceanogr. 19, 135-148.

Pinchuk, A. I., and Eisner, L. B. (2017). Spatial heterogeneity in zooplankton summer distribution in the eastern Chukchi Sea in 2012-2013 as a result of large-scale interactions of water masses. Deep Sea Res. Part II Top. Stud. Oceanogr. 135, 27-39. doi: 10.1016/j.dsr2.2016.11.003

Pisareva, M. N., Pickart, R. S., Spall, M., Nobre, C., Torres, D., Moore, G., et al. (2015). Flow of Pacific water in the western Chukchi sea: results from the 2009 RUSALCA expedition. Deep Sea Res. Part I Oceanogr. Res. Pap. 105, 53-73. doi: 10.1016/j.dsr.2015.08.011

Pomerleau, C., Nelson, R. J., Hunt, B. P., Sastri, A. R., and Williams, W. J. (2014). Spatial patterns in zooplankton communities and stable isotope ratios $(\delta 13 \mathrm{C}$ and $\delta 15 \mathrm{~N}$ ) in relation to oceanographic conditions in the sub-Arctic Pacific and western Arctic regions during the summer of 2008. J. Plankt. Res. 36, 757-775. doi: 10.1093/plankt/fbt129 
Questel, J. M., Clarke, C., and Hopcroft, R. R. (2013). Seasonal and interannual variation in the planktonic communities of the northeastern Chukchi Sea during the summer and early fall. Continent. Shelf Res. 67, 23-41. doi: 10.1016/ j.csr.2012.11.003

Shimada, K., Kamoshida, T., Itoh, M., Nishino, S., Carmack, E., McLaughlin, F., et al. (2006). Pacific Ocean inflow: influence on catastrophic reduction of sea ice cover in the Arctic ocean. Geophys. Res. Lett. 33:624.

Shoden, S., Ikeda, T., and Yamaguchi, A. (2005). Vertical distribution, population structure and lifecycle of Eucalanus bungii (Copepoda: Calanoida) in the Oyashio region, with notes on its regional variations. Mar. Biol. 146, 497-511. doi: 10.1007/s00227-004-1450-3

Skjoldal, H. R., Wiebe, P. H., Postel, L., Knutsen, T., Kaartvedt, S., and Sameoto, D. D. (2013). Intercomparison of zooplankton (net) sampling systems: results from the ICES/GLOBEC sea-going workshop. Prog. Oceanogr. 108, 1-42. doi: 10.1016/j.pocean.2012.10.006

Smoot, C. A., and Hopcroft, R. R. (2017). Depth-stratified community structure of Beaufort Sea slope zooplankton and its relations to water masses. J. Plankt. Res. 39, 79-91. doi: 10.1093/plankt/fbw087

Spear, A., Duffy-Anderson, J., Kimmel, D., Napp, J., Randall, J., and Stabeno, P. (2019). Physical and biological drivers of zooplankton communities in the Chukchi Sea. Polar Biol. 42, 1107-1124. doi: 10.1007/s00300-019-02498-0

Springer, A. M., McRoY, C. P., and Turco, K. R. (1989). The paradox of pelagic food webs in the northern Bering Sea-II. Zooplankton communities. Continent. Shelf Res. 9, 359-386. doi: 10.1016/0278-4343(89)90039-3

Stabeno, P., Kachel, N., Ladd, C., and Woodgate, R. (2018). Flow patterns in the eastern Chukchi Sea: 2010-2015. J. Geophys. Res. Oceans 123, 1177-1195. doi: 10.1002/2017jc013135

Weingartner, T., Fang, Y.-C., Winsor, P., Dobbins, E., Potter, R., Statscewich, H., et al. (2017). The summer hydrographic structure of the Hanna shoal region on the northeastern Chukchi Sea shelf: 2011-2013. Deep Sea Res. Part II Top. Stud. Oceanogr. 144, 6-20. doi: 10.1016/j.dsr2.2017.08.006
Wood, K. R., Bond, N. A., Danielson, S. L., Overland, J. E., Salo, S. A., Stabeno, P. J., et al. (2015). A decade of environmental change in the Pacific Arctic region. Prog. Oceanogr. 136, 12-31. doi: 10.1016/j.pocean.2015.05.005

Woodgate, R. A. (2018). Increases in the Pacific inflow to the Arctic from 1990 to 2015, and insights into seasonal trends and driving mechanisms from yearround Bering Strait mooring data. Prog. Oceanogr. 160, 124-154. doi: 10.1016/ j.pocean.2017.12.007

Woodgate, R. A., Aagaard, K., and Weingartner, T. J. (2005). A year in the physical oceanography of the Chukchi Sea: moored measurements from autumn 19901991. Deep Sea Res. Part II Top. Stud. Oceanogr. 52, 3116-3149. doi: 10.1016/j. dsr2.2005.10.016

Xu, Z., Zhang, G., and Sun, S. (2018). Inter-annual variation of the summer zooplankton community in the Chukchi Sea: spatial heterogeneity during a decade of rapid ice decline. Polar Biol. 41, 1827-1843. doi: 10.1007/s00300018-2324-3

Yamashita, Y., Yagi, Y., Ueno, H., Ooki, A., and Hirawake, T. (2019). Characterization of the water masses in the shelf region of the Bering and Chukchi Seas with fluorescent organic matter. J. Geophys. Res. Oceans 124, 7545-7556. doi: 10.1029/2019jc015476

Conflict of Interest: The authors declare that the research was conducted in the absence of any commercial or financial relationships that could be construed as a potential conflict of interest.

Copyright (c) $2020 \mathrm{Kim}, \mathrm{Cho}, \mathrm{La}$, Choy, Matsuno, Kang, Kim and Yang. This is an open-access article distributed under the terms of the Creative Commons Attribution License (CC BY). The use, distribution or reproduction in other forums is permitted, provided the original author(s) and the copyright owner(s) are credited and that the original publication in this journal is cited, in accordance with accepted academic practice. No use, distribution or reproduction is permitted which does not comply with these terms. 